\title{
SELEKSI DAN IDENTIFIKASI CENDAWAN ENDOFIT DI PERTANAMAN ORGANIK BAWANG MERAH LOKAL PALU
}

\section{SELECTION AND IDENTIFICATION OF ENDOPHYTIC FUNGUS AT LOCAL SHALLOT ORGANIC PLANTATION IN PALU}

\author{
Ratnawati $^{{ }^{*}}$, Kasman Jaya ${ }^{1}$, \\ ${ }^{1}$ Program Studi Agroteknologi, Fakultas Pertanian, Universitas Alkhairaat, \\ J1. Diponegoro, No. 39, Palu 94221, Sulawesi Tengah, Indonesia
}

\begin{abstract}
ABSTRAK
Penelitian ini bertujuan untuk menyeleksi dan mengidentifikasi cendawan endofit dari pertanaman organik bawang merah lokal Palu. Cendawan endofit diperoleh dari lahan organik tanaman bawang merah bagian rizosfer kedalaman 1-10 cm, dengan menggunakan metode diagonal sampling, sehingga ditemukan 10 titik pengambilan sampel. Isolat cendawan yang telah dimurnikan kemudian diidentifikasi secara makroskopis dan mikroskopis. Hasil seleksi dan identifikasi isolat diperoleh 12 isolat cendawan endofit dari pertanaman organik bawang merah lokal Palu. Tiga isolat cendawan endofit yang unidentified, dan 9 isolat cendawan endopit yakni; Penicilium sp,Trichoderma mf 1, Aspergillus niger, Fusarium sp, Trichoderma mf 2, Asperegillus flavus, Trichoderma mf 3, Fusarium sp, Trichoderma mf 4.
\end{abstract}

Kata kunci: Cendawan Endofit; Bawang Merah Lokal, Organik

\section{ABSTRACT}

This study aims to select and identify endophytic fungi from local shallot organic plantations in Palu. Endophytic fungi were obtained from the organic land of shallot plants in the rhizosphere at a depth of 1$10 \mathrm{~cm}$, using the diagonal sampling method, so that 10 sampling points were found. The purified fungal isolates were then identified macroscopically and microscopically. The results of the selection and identification of isolates obtained 12 isolates of endophytic fungi from the local organic shallot plantations of Palu. Three isolates of unidentified endophytic fungi, and 9 isolates of endophytic fungi, namely; Penicillium sp,Trichoderma mf 1, Aspergillus niger, Fusarium sp, Trichoderma mf 2, Asperegillus flavus, Trichoderma mf 3, Fusarium sp, Trichoderma $\mathrm{mf} 4$.

\section{Keywords: Endophytic Fungu; Lokal Shallot Palu, Organic}

\section{Pendahuluan}

Bawang merah lokal Palu (Allium cepa $\mathrm{L}$ var.Aggregatum group) adalah salah satu jenis bawang merah yang banyak dikembangkan di Provinsi Sulawesi Tengah khususnya di lembah Palu. Budidaya tanaman bawang merah lokal Palu umumnya dikembangkan secara konvensional yakni pertanian yang memerlukan input (masukan) bahan-bahan anorganik yang tinggi terutama bahan kimia pertanian seperti pupuk sintetis dan pestisida dengan dosis yang tinggi secara terus-menerus (Jaya et al, 2015;

\footnotetext{
${ }^{*}$ Penulis Korespondensi.

E-mail : ratnawatikjsaad@yahoo.co.id

Telp: +62-81341053516
}

Jaya 2017; Ratnawati dan Jaya, 2020). Beberapa petani bawang merah telah mengupayakan pertanian organik dengan pemanfaatan bahanbahan alami (lokal) tanpa menggunakan bahanbahan kimia sintesis seperti pupuk, pestisida (kecuali bahan yang diperkenankan).

Hasil eskplorasi Ratnawati et al (2020), pada lahan pertanaman bawang merah lokal Palu dengan intensitas penggunaan pestisida berbeda, ditemukan jumlah dan jenis cendawan endofit berbeda. Frekuensi aplikasi pestisida rendah pada rizosfer, seluruhnya cendawan endopit, yaitu Aspergellus niger, Aspergellus flavus, Fusarium sp, Gliocladium, Paenicillium sp dan Trichoderma sp ditemukan pada lahan yang diaplikasi pestisida sedang. Pada lahan dengan aplikasi tinggi dominan ditemukan cendawan 
unidentified dengan keanekaragaman cendawan yang rendah. Cendawan edofit menurut Sopialena, dkk. (2019) mampu menjadi agensia hayati pengendali hama dan penyakit. Cendawan endofit adalah cendawan yang dapat berasosiasi dengan jaringan tanaman dan tidak menimbulkan kerugian pada tanaman (Faeth, 2002; Nur Amin, et al, 2017). Cendawan endofit dapat menginfeksi tanaman sehat karena dapat menghasilkan metabolit sekunder seperti mikotoksin, antibiotik maupun enzim yang dapat melindungi tanaman dari patogen virulen serta dapat membuat taman toleran terhadap tekanan biotik (Budiprakoso, 2010). Bosah et al., (2010); Sayang (2010); Karim, et al., (2013), menyebutkan cendawan endofit dapat memproduksi metabolit sekunder atau enzim seperti enzim selulose, kitinase dan pektinase

Pemanfaatan cendawan endofit terus dikembangkan mengingat perannya begitu penting dalam tanaman inang, terlebih setelah adanya laporan Garry A. Strobel mengenai kemampuan cendawan endofit meniru metabolisme metabolit sekunder dari tanaman inangnya (Agusta 2009). Olehnya penting dilakukan penelitian tentang seleksi dan isolasi cendawan endofit pada pertanaman organik bawang merah sebagai antisipasi peningkatan produksi dan biokontrol. Berdasarkan uraian tersebut, penelitian ini bertujuan untuk menyeleksi dan mengidentifikasi cendawan endofit dari pertanaman organik bawang merah lokal Palu.

\section{Metode Penelitian}

Penelitian dilakukan di Desa Oloboju Kecamatan Sigi Biromaru Kabupaten Sigi untuk pengambilan sampel tanaman. Identifikasi dilaksanakan di Laboratorium Unisa dan Untad Palu. Penelitian dimulai dari bulan Agustus 2020 sampai dengan Desember 2020.

Bahan yang digunakan dalam penelitian ini adalah; Alkohol 70\%, Media PDA, Spritus, dan Aquadest. Alat yang digunakan adalah; Scalpel, Autoklaf, Gelas Erlenmeyer, Cawan Petri, Jarum Inokulasi, Pinset, Aluminium Foil, Mikroskop, Kaca Objek, Pipet Tetes, Akuades, Kamera, Kertas Tissue, Kain Kasa,,Kapas,Cook Borrer, Alat Tulis Dan Buku Indentifikasi.

Penentuan lokasi pada pertanaman bawang merah di Desa Oloboju dilakukan secara purposive, diawali dengan kegiatan survey untuk memastikan bahwa petani bawang merah tidak menggunakan bahan kimia, pupuk sintesis dan pestisida dalam kegiatan budidayanya, sehingga dapat disimpulkan menggunakan sistem pertanian organik. Selanjutnya dilakukan pengambilan sampel berupa tanah bagian rizosfer yang diambil untuk sampel yaitu kedalaman 1-10 $\mathrm{cm}$ pada tanaman bawang merah, dilakukan dengan menggunakan metode diagonal sampling, sehingga ditemukan 10 titik pengambilan sampel yang berbeda, selanjutnya masing-masing sampel dimasukkan dalam kantong plastik, dan masingmasing diberi label serta disimpan dalam cooler box yg berisi es, selanjutnya sampel disimpan dalam lemari es pada suhu $4^{0} \mathrm{C}$ hingga pengerjaan dilaksanakan di Laboratorium (Gofar,2003).

Sampel yang telah diperolah dari lahan organik dilanjutkan dengan kegiatan identifikasi di Laboratorium. Masing-masing sampel tanah ditimbang sebanyak 10 gr. Kemudian dilakukan pengenceran sampai $10^{-4}$, setelah itu diisolasi pada medium Potato Dekstrose Agar (PDA) dengan cara mengambil $0,1 \mathrm{ml}$ semua sampel yang telah diencerkan dengan metode tanam sebar dan dilakukan didalam ruang laminar air flow secara aseptik, setelah selesai diinkubasi pada suhu ruang selama 3-14 hari. Koloni yang tumbuh pada medium PDA dengan ciri cendawan yang berbeda, selanjutnya dihitung, diisolasi dan dimurnikan kembali sampai didapatkan biakan murni untuk dijadikan kultur stok uji selanjutnya. Cendawan-cendawan yang tumbuh kemudian diberi tanda/label.

\section{Hasil dan Pembahasan}

Hasil isolasi mikroba yang dilakukan pada lahan tanaman bawang organik di lahan petani diperoleh sebanyak 56 isolat, terdapat beberapa isolat yang secara makroskopis sama. Hasil seleksi tahap kedua terdapat 36 isolat cendawan yang berpotensi sebagai isolat antagonis. Kemampuan pertumbuhan koloni setiap isolat secara makroskopis berbeda sehingga pada tahap seleksi ke tiga didapatkan isolat yang pertumbuhan koloninya diatas $50 \%$ adalah sebanyak 12 isolat. Karakteristik pertumbuhan koloni tunggal selama 7 hari pada setiap isolat dapat dilihat pada Tabel 1 .

Tabel 1 menunjukkan bahwa dari 12 isolat cendawan yang terseleksi dari lahan pertanaman bawang merah organik, terlihat bahwa pada setiap isolat mempunyai karakterisasi yang berbeda berdasarkan morfologi perkembangan warna dan bentuknya. Selanjutnya pada Tabel 2, tersajikan karakterisasi isolat secara mikroskopis berdasarkan buku identifikasi Watanabe (2002). 
Tabel 1. Karakteristik Pertumbuhan Koloni Tunggal Selama 7 Hari Pada Setiap Isolat

\begin{tabular}{|c|c|c|c|}
\hline \multirow{2}{*}{$\begin{array}{l}\text { Kode } \\
\text { Isolat }\end{array}$} & \multicolumn{2}{|c|}{ Warna Koloni } & \multirow{2}{*}{$\begin{array}{l}\text { Bentuk } \\
\text { Kolon }\end{array}$} \\
\hline & $\begin{array}{l}\text { Tampak } \\
\text { Atas (A) }\end{array}$ & $\begin{array}{c}\text { Tampak Bawah } \\
\text { (B) }\end{array}$ & \\
\hline C.1 & Putih & $\begin{array}{l}\text { Putih } \\
\text { Kekuningan }\end{array}$ & Bulat \\
\hline C. 2 & $\begin{array}{l}\text { Putih } \\
\text { Keabuan }\end{array}$ & $\begin{array}{l}\text { Putih } \\
\text { Kekuningan }\end{array}$ & Bulat \\
\hline C. 3 & Hijau & $\begin{array}{l}\text { Hijau } \\
\text { Kekuningan } \\
\text { kemerahan }\end{array}$ & Bulat \\
\hline C. 4 & Hijau & Hijau Pudar & Bulat \\
\hline C. 5 & $\begin{array}{l}\text { Hitam } \\
\text { pudar }\end{array}$ & Putih Kotor & Bulat \\
\hline C. 6 & $\begin{array}{l}\text { Putih } \\
\text { Keruh }\end{array}$ & $\begin{array}{l}\text { Putih } \\
\text { Kekuningan }\end{array}$ & Bulat \\
\hline C. 7 & $\begin{array}{l}\text { Putih } \\
\text { Kapas } \\
\text { orange }\end{array}$ & $\begin{array}{l}\text { Putih } \\
\text { Kekuningan }\end{array}$ & Bulat \\
\hline C. 8 & $\begin{array}{l}\text { Putih } \\
\text { Keabuan }\end{array}$ & Putih kotor & Bulat \\
\hline C. 9 & Hijau & $\begin{array}{l}\text { Hijau orange } \\
\text { kekuningan }\end{array}$ & Bulat \\
\hline C. 10 & $\begin{array}{l}\text { Hijau } \\
\text { Keabuan }\end{array}$ & Putih Kotor & Bulat \\
\hline C. 11 & $\begin{array}{l}\text { Putih } \\
\text { Kapas } \\
\text { Orange }\end{array}$ & $\begin{array}{l}\text { Putih Agak } \\
\text { Kuning }\end{array}$ & Bulat \\
\hline C. 12 & $\begin{array}{l}\text { Hijau } \\
\text { Putih }\end{array}$ & Putih Kotor & Bulat \\
\hline
\end{tabular}

Berdasarkan karakterisasi isolat secara makroskopis dan mikroskopis yang diperoleh dari rizosfer tanaman bawang merah lokal Palu yang ditanam secara organik, diperoleh 12 isolat yang mempunyai karakterisasi yang berbeda berdasarkan morfologi perkembangan warna dan bentuknya. Ke 12 isolat yang diperoleh secara mikroskopis ada 3 cendawan yang tergolong Unidentified (C1,C2 dan C6), ketiga isolat tersebut merupakan cendawan antagonis, karena dari hasil pertumbuhan koloni ketiga isolat pertumbuhannya rata-rata diatas $50 \%$, namun ketiga isolat tersebut secara mikroskopis merupakan miselia sterelia sehingga tidak dapat diidentifikasi lebih lanjut.

Hasil pengamatan makroskopis dan mikroskopis terhadap isolat C3 adalah sesuai dengan karakter Penicillium sp. Koloni berwarna hijau pada bagian permukaan sedangkan bagian bawah berwarna kuning kemerahan, memiliki septa, konidiofor bercabang dan konidia yang oval. Hal ini sesuai dengan pendapat Semangun (2006) dan Ratnawati et al. (2020) bahwa cendawan Penicillium sp mempunyai hifa yang bersepta, miselium bercabang, konidia berbentuk oval seperti rantai.

Pengamatan secara makroskopis dan mikroskopis pada isolat $\mathrm{C} 4, \mathrm{C} 8$ dan $\mathrm{C} 10$ koloninya berwarna hijau dan bentuknya bulat sementara secara mikroskopis bentuk konidiofornya tegak tersusun secara vertikal, fialid pendek dan tebal. Berdasarkan karakteristik tersebut isolat $\mathrm{C} 4$, isolat $\mathrm{C} 8$, dan isolat $\mathrm{C} 10$ adalah Trichoderma, sp dengan masing-masing koloni cendawan pada awal pertumbuhannya berwarna putih, lama kelamaan berubah menjadi warna hijau sedangkan bagian bawahnya berwarna putih kehijauan, kecuali pada isolat $\mathrm{C}$ 12 pertumbuhan awal koloni memperlihatkan warna hijau yang menyebar pada permukaan cawan. Setiap spesies Trichoderma mempunyai warna dan bentuk koloni yang berbeda Rifai dan Aeny (1996); Gusnawaty, dkk. (2014) dan Ratnawati et al. (2019). Trichoderma sp adalah salah satu cendawan endofit yang dapat hidup pada semua bagian jaringan tanaman baik di bawah tanah maupun di atas tanah yaitu akar, batang dan daun (Kusari et al., 2012; Rosmana et al., 2018).

Warna koloni pada awal pertumbuhan bagian atas putih lama kelamaan menjadi hitam, bagian bawah krem, permukaan berbulu halus, tepi koloni rata. Konidia berbentuk bulat oval, warna konidia hialin, permukaan konidiofor halus, phialid berbentuk tegak, hifa bersepta. Karakteristik tersebut adalah isolat C5 dan isolat C9. 
Jurnal Agratech 11 (1) 13-19, Juni 2021

e-ISSN : 2621-7236

p-ISSN : 1858-134X

Tabel 2. Karakteristik Morfologi Cendawan Endofit

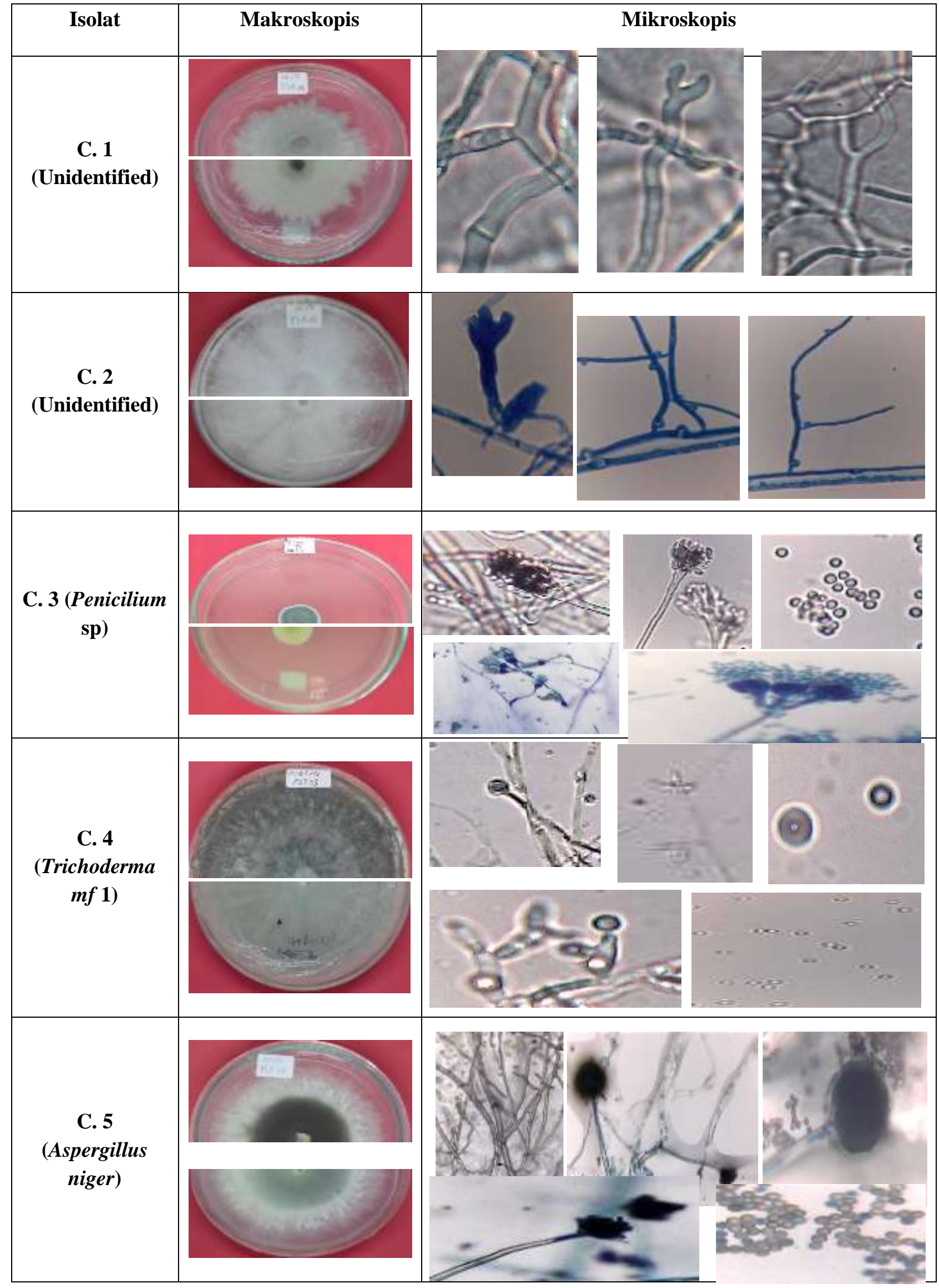


Jurnal Agratech 11 (1) 13-19, Juni 2021

e-ISSN : 2621-7236

p-ISSN : 1858-134X

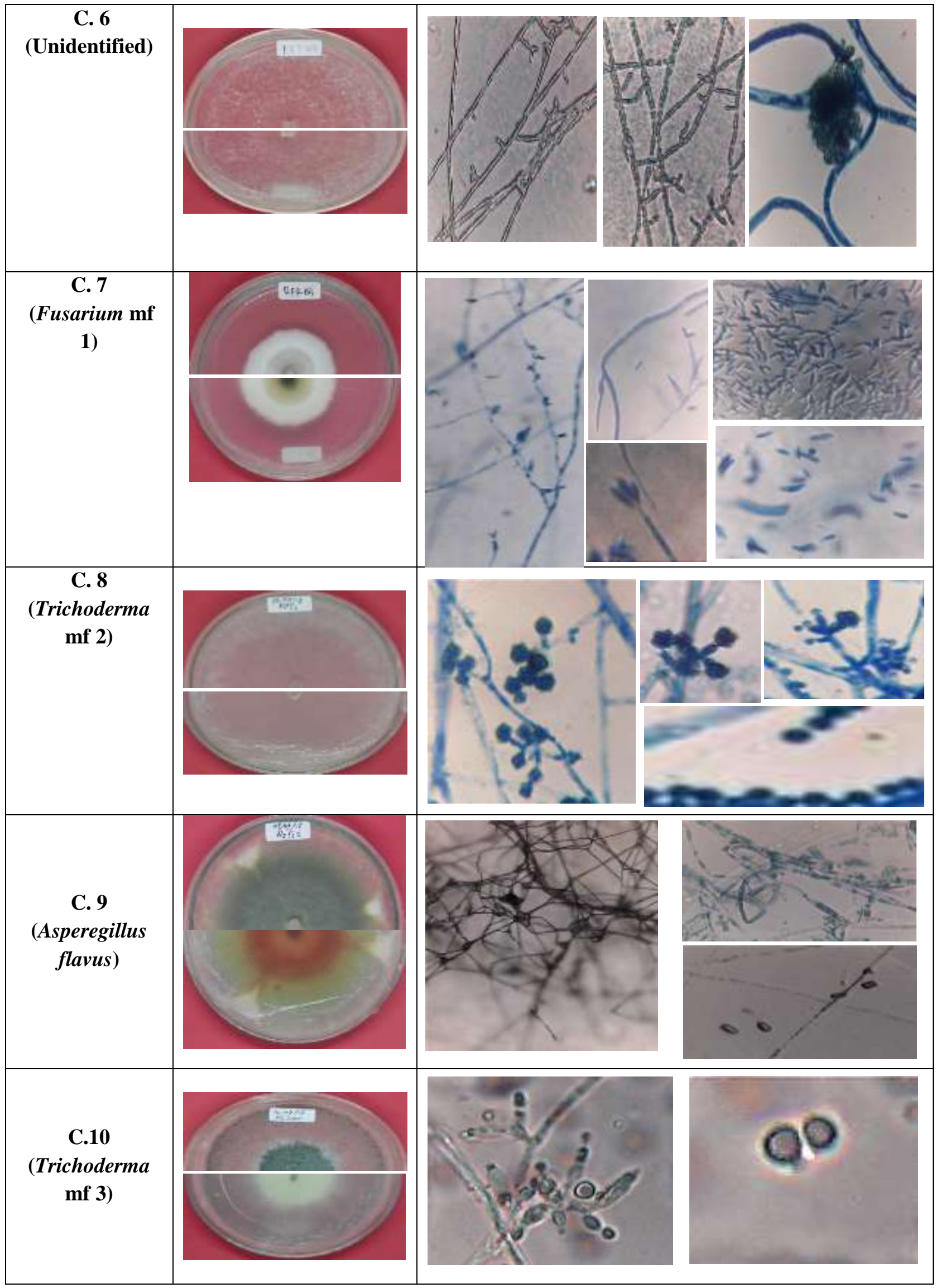




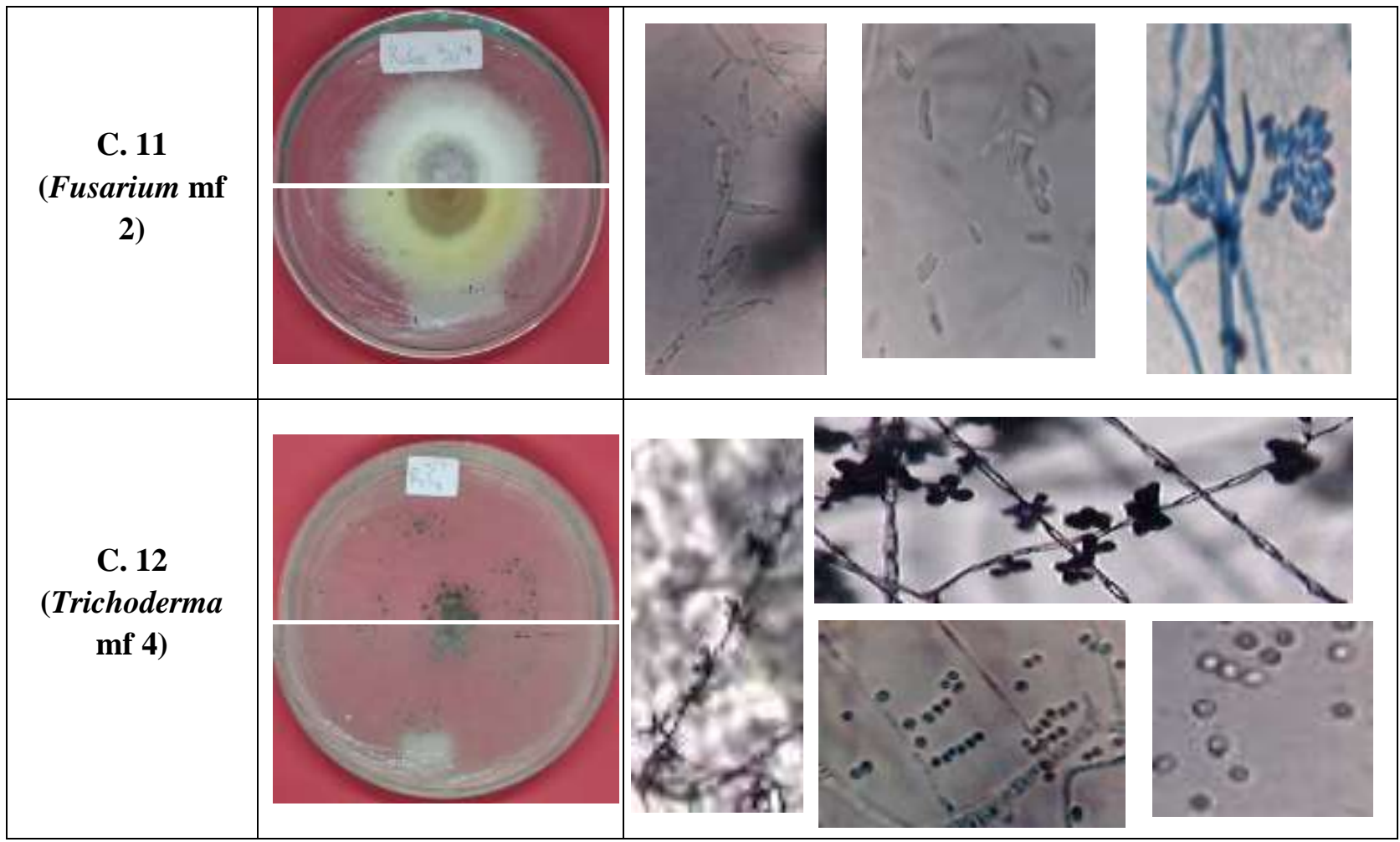

Pengamatan makroskopis isolat C5 sesuai karakter kelompok Asperegillus niger dan isolat C9 adalah sesuai karakter kelompok Asperegillus plavus hal ini dikarenakan adanya perbedaan warna koloni. Permukaan atas isolat C5 adalah hitam sementara permukaan atas koloni isolat C9 adalah hijau pada bagian tengah dan putih pada pinggirannya. Secara makroskopis dan mikroskopis cendawan Aspergillus mudah dikenali dan dibedakan dari cendawan marga lain, Barnett, 1995 dan Ilyas, 2006 mengemukakan secara mikroskopis cendawan Aspergillus mudah dikenali dan dibedakan dari cendawan marga lain, yaitu memiliki konidiofor yang tegak, tidak bersepta, tidak bercabang, dan ujun konidiofor membengkak membentuk vesikel. Pada permukaan vesikel ditutupi fialid yang menghasilkan konidia. Konidia tersusun satu sel (tidak bersepta), globus memiliki warna yang beragam dan tersusun membentuk rantai basipetal.

Pada pengamatan isolat C7 dan isolat C11 secara makroskopis pertumbuhan koloninya baik warna dan bentuk sama baik pada permukaan bagian atas maupun pada bagian bawah. Ke dua isolat tersebut memperlihatkan warna koloni putih pada bagian tengahnya, tepinya berwana orange, pertumbuhan koloni rata serta miseliumnya teratur. Secara mikroskopis ke dua isolat tersebut memperlihatkan bentuk makrokonidia hialin mempunyai 2 hingga beberapa sel berbentuk seperti sabit dengan ujung yang agak bengkok. Hasil pengamatan makroskopis dan mikroskopis isolat ini sesuai dengan karakter Fusarium sp. Golongan Fusarium dicirikan dengan struktur tubuh berupa miselium bercabang, hialin, dan bersekat (septat) dengan diameter 2-4 $\mu \mathrm{m}$ (Semangun, 2006).

\section{Kesimpulan}

Berdasarkan hasil seleksi dan identifikasi, diperoleh 12 isolat cendawan yang berpotensi sebagai cendawan endofit dari pertanaman organik bawang merah lokal Palu. Tiga isolat cendawan yang unidentified, dan 9 isolat cendawan endofit yakni; Penicillium $\mathrm{sp}$, Trichoderma $\mathrm{mf} 1$, Aspergillus niger, Fusarium mf 1, Trichoderma mf 2, Asperegillus flavus, Trichoderma $\mathrm{mf} 3$, Fusarium $\mathrm{mf} 2$, Trichoderma $\mathrm{mf} 4$.

\section{Daftar Pustaka}

Agusta, A 2009, Biologi dan Kimia Jamur Endofit, Penerbit ITB, Bandung.

Bosah O,. C.A. Igeleke and V.I. Omonusi. 2010. In Vitro Microbial Control of Pathogenic Sclerotium rolfsii. Intr. J. Agric. Biol 12" 474-476. 
Budiprakoso, B. 2010. Pemanfaatan Cendawan Endofit sebagai Penginduksi Ketahanan Tanaman Padi terhadap Wereng Coklat Nilaparvata lugens (Stal). (Hemiptera: Delphacidae). Institut Pertanian Bogor.

Faeth, S. H. 2002. Are endophytic fungi defensive plant mutualists? Oikos, 98(1), 25-36. http://doi.org/10.1034/j.16000706.2002.980103.x

Gofar, N. 2003.Eksplorasi konsorsium mikroba daunasal tumbuhan dari ekosistem air hitam Kalimantan Tengah dan aplikasinya sebagai pemacu pertumbuhan tanaman jagung pada ultisol (Disertasi). Bandung (ID): Program Pascasarjana Universitas Padjajaran.

Gusnawaty HS, Muhammad Taufik, Leni Triana dan Asniah. 2014. Karakterisasi Morfologis Trichoderma Spp. Indigenus Sulawesi Tenggara. Jurnal Agroteknos Juli 2014 Vol. 4 No. 2. Hal 87-93

Ilyas, M. 2006. Isolasi dan Identifikasi Kapang pada Relung Rizosfir Tanaman di Kawasan Cagar Alam Gunung Mutis , Nusa Tenggara Timur. Biodiversitas, 7(83), 216-220. http://doi.org/10.13057/biodiv/d070304

Kusari, S., Verma, V.C., Lamshoeft, M., Spiteller, M., 2012. An endophytic fungus from Azadirachta indica juss that produces azadirachtin. World J. Microbiol Biotechnol. 28:1287-1294.

Jaya,K., Muhammad Ardi, Sylvia Sjam dan Gufran D.D., 2015. Onion Farmers Behavior In Ecosystem-Based Pest (EBP) Control In Sigi District Of Central Sulawesi Province. Man In India, 95:649659. SerialPublication.

Jaya,K..2017. Perilaku Petani Kajian Empirik Dalam Pengelolaah Hama.Yamiba. Jakarta.

Nur Amin, La Daha and Nurariaty Agus., 2017. Endophytic Fungi as Biopesticide Againts Rice Black Bug on Rice Plant. Research Journal of Pharmaceutical, Biological and Chemical Sciences 8(2).

Ratnawati, Sylvia Sjam, Ade Rosmana dan Untung Surapati Tresnaputra. 2019. Impact of Pesticides on the Diversity of Fungi at
Local Shallot in Palu, Indonesia. Int.J.Curr.Microbiol.App.Sci.2019.8(8):73 0-738

DOI:

https://doi.org/10.20546/ijcmas. 2019.808 .083

Ratnawati R., Sylvia Sjam, Ade Rosmana dan Untung Surapati Tresnaputra.2020. Endophytic Trichoderma Species of Palu Valley Shallot Origin with Potential for Controlling Purple Blotch Pathogen Alternaria pori. International Journal of Agriculture and Biology. Volume 23 Issue 05, 2020. 977-982. DOI: $10.17957 / \mathrm{IJAB} / 15.1376$

Ratnawati dan Kasman Jaya. 2020. Keanekaragaman Arthropoda Pada Pertanaman Bawang Merah Dengan Intensitas Aplikasi Pestisida Yang Berbeda Di Kabupaten Sigi. Jurnal Agrotech. Vol.10.No.2 (2020). DOI: https://doi.org/10.31970/agrotech.v10i2

Rifai M, Mujim Sdan Aeny.TN.1996. Pengaruh lama investasi Trichoderma viride terhadap intensitas serangan Phytiumsp. pada Kedelai. Jurnal Penelitian Pertama VII (8): 20-25.

Rosmana A, Sylvia Sjam., Asman Asman., Nurul Jihad Jayanti., Satriana Satriana., Andi Tenri Padang., Andi Akbar Hakkar. 2018. Systemic Deployment of Trichoderma asperellum in Theobrama cacao Regulator Co-occuring Dominant Fungal Endophytes Colonization. Journal Of Pure and Applied Microbiology. Vol.12(3); 1071-1084.

Sayang,Y. 2010. Kajian Keragaman Mikoba Antagonis Rizosfer Dan Pemanfaatannya dalam Mengedalikan Penyebab Penyakit Busuk Umbi (Fusarium oxysporum Schecht) Pada Tanaman Bawang Merah. Jurnal Sains \& Teknologi vol.9 no.3 : 165170.

Semangun, H. 2006. Penyakit-Penyakit Tanaman Hortikultura di Indonesia. Gadjah Mada University Press, Yogyakarta.

Sopialena, S., Sofian, S., \& Allita, L. D. 2019. Diversitas Jamur Endofit Pada Tanaman Padi (Oryza sativa L.) dan Potensinya Sebagai Pengendali Hama. Jurnal Agroekoteknologi Tropika Lembab, 2(1), 44-49. doi:10.35941/JATL. 